\title{
Methylamine and Ammonia Transport in Stemphylium botryosum
}

\author{
By ADINA BREIMAN AND ISAAC BARASH \\ Department of Botany, The George S. Wise Faculty for Life Sciences, \\ Tel-Aviv University, Ramat-Aviv, Tel-Aviv, Israel
}

(Received 29 May 1979)

$\left[{ }^{14} \mathrm{C}\right]$ Methylamine was transported into mycelial cells of Stemphylium botryosum by a specific and energy-dependent transport system having an optimum at $\mathrm{pH} 6.0$, a $K_{\mathrm{m}}$ of $12.5 \mu \mathrm{M}$ and a $V_{\max }$ of $4.1 \mu \mathrm{mol}(\mathrm{g} \text { dry wt) })^{-1} \mathrm{~min}^{-1}$; uptake occurred against a concentration gradient. $\mathrm{NH}_{4}{ }^{+}$competitively inhibited methylamine transport with higher affinity towards the latter system. Sucrose and nitrate were required during transport for maximal activity. Highest transport activity developed in nitrate-grown mycelium. Nitrogen starvation decreased the activity by approximately $60 \%$. Preloading of mycelium with glutamine, asparagine or ammonia almost completely prevented methylamine uptake. Transport activity was inversely proportional to the intracellular concentration of the L-amides. It is postulated that ammonia uptake might be regulated by L-amides rather than by ammonia.

\section{INTRODUCTION}

Ammonia in high concentration is toxic to animals and higher plants (Warren, 1962) and may accumulate to inhibitory levels in some fungi (Cochrane, 1958; Gilpatrick, 1969). Nevertheless, the filamentous fungus Stemphylium botryosum can grow on high ammonia concentrations without being affected in its growth rate or in the composition of various cell constituents (Breiman, 1978). These results suggest that the intracellular ammonia concentration might be regulated by the entry of ammonia into the cells and/or its assimilation into organic nitrogen.

Ammonia transport systems in mycelial fungi have been described for Penicillium chrysogenum (Hackette et al., 1970) and Aspergillus nidulans (Pateman et al., 1974; Cook \& Anthony, $1978 a, b)$. Although the ammonia transport systems in these fungi and in yeast (Roon et al., 1975) share many common properties, differences in regulation might exist. Thus ammonia transport is derepressed approximately 800 -fold in $P$. chrysogenum during nitrogen starvation (Hackette et al., 1970) whereas the activity of the Saccharomyces cerevisiae system changes very little (Roon et al., 1977).

We have previously reported that the assimilation of ammonia via NADP-specific glutamate dehydrogenase in $S$. botryosum is regulated by L-asparagine and L-glutamine (Breiman \& Barash, 1978). It was therefore of interest to determine whether the same factors also regulate the entry of ammonia. The object of the present study was to characterize the ammonia transport system and its possible regulation in $S$. botryosum.

\section{METHODS}

Organism and culture conditions. A wild-type strain of Stemphylium botryosum Wallroth (Breiman \& Barash, 1976) was used throughout these studies. Mycelium was grown in Roux bottles containing $100 \mathrm{ml}$ liquid medium and incubated for $5 \mathrm{~d}$ at $25^{\circ} \mathrm{C}$. Growth medium was made in $0.1 \mathrm{M}$-potassium phosphate buffer pH 6.5 and contained (mM): $\mathrm{MgSO}_{4}, 2 ; \mathrm{KCl}, 6 \cdot 7 ; \mathrm{K}_{2} \mathrm{HPO}_{4}, 1 \cdot 2 ; \mathrm{FeCl}_{3}, 0.06$; sucrose, 30; $\mathrm{KNO}_{3}, 50$; and chloramphenicol, $\mathbf{0} \cdot 15$. The mycelium was removed from the growth medium, washed and dispersed in 


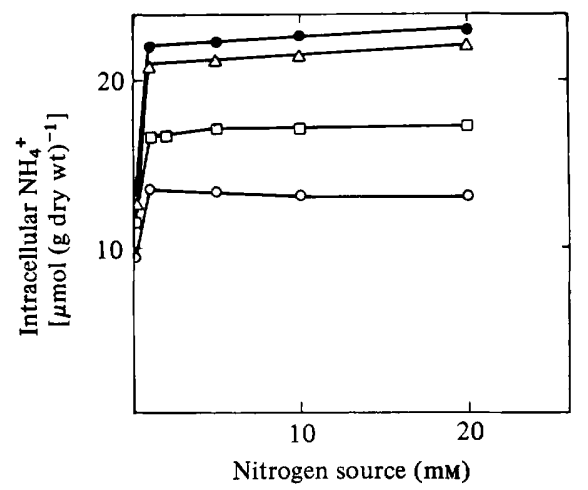

Fig. 1

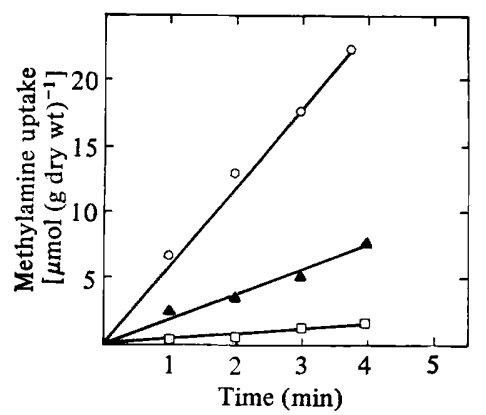

Fig. 2

Fig. 1. Effect of various nitrogen sources at different concentrations on the accumulation of intracellular $\mathrm{NH}_{4}{ }^{+}$in $S$. botryosum. $\mathrm{NH}_{4}{ }^{+}$determinations were carried out after $1 \mathrm{~h}$ incubation in the presence of $\mathrm{KNO}_{3}(\bigcirc)$, L-asparagine $(\square), \mathrm{NH}_{4} \mathrm{Cl}(\triangle)$ or L-glutamine $(\boldsymbol{O})$.

Fig. 2. Effect of sucrose and nitrate on methylamine transport. The fungus was grown in nitrate medium at $25^{\circ} \mathrm{C}$ for $5 \mathrm{~d}$. The mycelium was then removed, washed in deionized water and divided into four parts. Each part was transferred into a different medium and used for transport assay as described in Methods. The flasks were preincubated for $10 \mathrm{~min}$ prior to the addition of $\left[{ }^{14} \mathrm{C}\right] \mathrm{methyl}-$ amine. Media used were $0 \cdot 1 \mathrm{~mm}$-phosphate buffer, $\mathrm{pH}$, alone or with $10 \mathrm{~mm}-\mathrm{KNO}_{3}(\square)$, buffer plus $15 \mathrm{~mm}$-sucrose $(\boldsymbol{A})$ and buffer plus sucrose plus $\mathrm{KNO}_{3}(O)$.

$0 \cdot 1 \mathrm{M}$-potassium phosphate buffer $\mathrm{pH} 6.0$, containing $15 \mathrm{~mm}$-sucrose and $10 \mathrm{~mm}-\mathrm{KNO}_{3}$, as described earlier (Breiman \& Barash, 1976).

Transport of methylamine. This was measured in Erlenmeyer flasks ( $100 \mathrm{ml})$ containing $20 \mathrm{ml}$ cell suspension. The fiasks were shaken on a reciprocal shaker at $30^{\circ} \mathrm{C}$ for $5 \mathrm{~min}$ prior to the addition of the radioactive substrate and during the experiment. $\left[{ }^{14} \mathrm{C}\right]$ Methylamine was used as the ammonia analogue for characterization of the $\mathrm{NH}_{4}{ }^{+}$transport system (Hackette et al., 1970). The reaction was started by a rapid addition of $30 \mu \mathrm{M}-\left[{ }^{14} \mathrm{C}\right]$ methylamine $\left(3 \cdot 2 \times 10^{5}\right.$ c.p.m. $\left.\mu \mathrm{mol}^{-1}\right)$ to the cell suspension. Samples $(4 \mathrm{ml}, 10 \mathrm{mg}$ dry wt $)$ were taken every $30 \mathrm{~s}$ for at least $3 \mathrm{~min}$. Uptake was terminated by filtering with suction through Whatman GF/C filter paper $(2.5 \mathrm{~cm}$ diam.) and rinsing twice with $5 \mathrm{ml}$ of cold solution containing $1 \mathrm{~mm}$-methylamine. The mycelial pad was peeled off the filter and counted for radioactivity (Breiman \& Barash, 1976). Results were expressed as $\mu \mathrm{mol}$ methylamine transported ( $\mathrm{g}$ dry wt mycelium) ${ }^{-1} \mathrm{~min}^{-1}$.

Determination of the intracellular $\mathrm{NH}_{4}{ }^{+}$concentration. The mycelium was washed thoroughly with doubledistilled water and $300 \mathrm{mg}$ lyophilized cells were extracted twice with $2 \mathrm{ml}$ double-distilled water at $90^{\circ} \mathrm{C}$ for $30 \mathrm{~min} . \mathrm{NH}_{4}{ }^{+}$was assayed in the supernatant by the method of Buttery \& Rousell (1971), using a NADP-glutamate dehydrogenase-mediated reaction. The pool of amides and amino acids in the mycelium was estimated as previously described (Breiman \& Barash, 1978). Extraction of mycelium for $\left[{ }^{14} \mathrm{C}\right] \mathrm{methyl-}$ amine determination was carried out as described for $\mathrm{NH}_{4}{ }^{+}$except that the mycelium was washed in the presence of $1 \mathrm{~mm}$ unlabelled methylamine. Extracts were applied to thin layers of cellulose for chromatography and developed in butan-1-ol/acetic acid/water (12:3:5, by vol.) and propan-2-ol/ethanol/9\% $\mathrm{HCl}$ ( $75: 75: 50$, by vol.). Methylamine was detected on the chromatogram using ninhydrin reagent, with amino acids, $\mathrm{NH}_{4}{ }^{+}$and methylamine incorporated as standards.

Chemicals. $\left[{ }^{14} \mathrm{C}\right]$ Methylamine hydrochloride $\left(56 \mathrm{mCi} \mathrm{mmol}^{-1}\right)$ was purchased from The Radiochemical Centre, Amersham. Ethylamine and dimethylamine hydrochloride were obtained from Sigma. All other chemicals used were of analytical grade.

\section{RESULTS AND DISCUSSION}

\section{Effect of nitrogen source on accumulation of intracellular $\mathrm{NH}_{4}^{+}$}

Mycelium was starved of nitrogen by agitation in Erlenmeyer flasks containing growth medium without nitrate for $2 \mathrm{~h}$ at $29^{\circ} \mathrm{C}$. It was then removed by suction filtration, washed (Breiman \& Barash, 1976) and transferred into the same medium containing different nitrogen sources. Ammonia was determined after shaking for a further hour. The concen- 
Table 1. Inhibition of methylamine transport by amines, amides and $\mathrm{NH}_{4}^{+}$

The initial rate of transport was assayed under standard assay conditions, the labelled substrate and potential inhibitors $(0 \cdot 1 \mathrm{~mm})$ being added simultaneously.

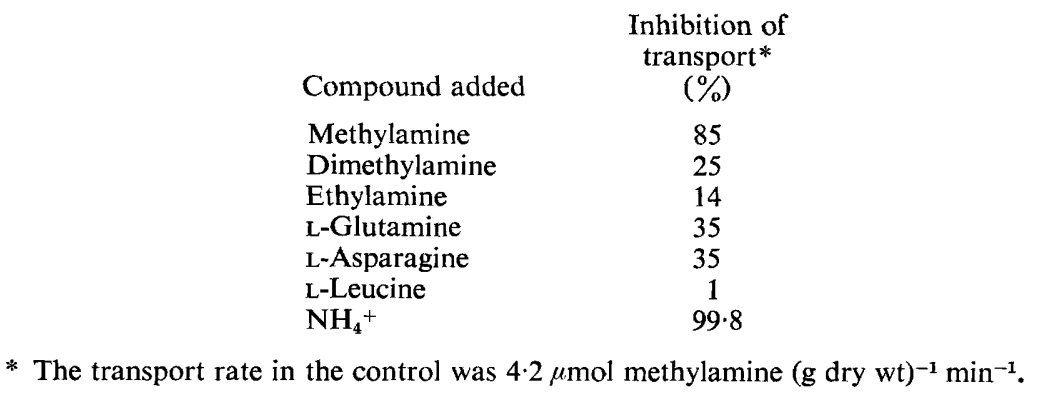

tration of intracellular $\mathrm{NH}_{4}{ }^{+}$in the presence of $\mathrm{NH}_{4} \mathrm{Cl}$ and $\mathrm{L}$-glutamine was about $50 \%$ higher than in the presence of $\mathrm{KNO}_{3}$; L-asparagine exerted an intermediate effect (Fig. 1). The concentration of intracellular $\mathrm{NH}_{4}{ }^{+}$was maximal after adding approximately $1 \mathrm{~mm}$ nitrogen source and did not increase further. These results support the view that the internal $\mathrm{NH}_{4}{ }^{+}$concentration must be regulated. Since external $\mathrm{NH}_{4}{ }^{+}$represses $\mathrm{NH}_{4}{ }^{+}$assimilation in $S$. botryosum (Breiman \& Barash, 1978), it appears that its entry into the mycelium is the major mechanism for controlling the level of intracellular $\mathrm{NH}_{4}{ }^{+}$.

\section{Effect of nitrogen and carbon sources on transport of $\left[{ }^{14} \mathrm{C}\right]$ methylamine}

To determine the effect of nutritional conditions on methylamine uptake, the initial transport rates were compared in the presence or absence of sucrose, nitrate or both (Fig. 2). Maximal transport was observed in the presence of sucrose and nitrate. When nitrate was omitted, the transport rate decreased by more than $50 \%$. Uptake of methylamine showed a strict requirement for sucrose or some other readily assimilated carbon source. The need for carbon might reflect the requirement for energy coupling in this active transport system, whereas the effect of nitrate could result from the influence of protein synthesis. These results are entirely different from those obtained with $P$. chrysogenum and $A$. nidulans in which maximal transport took place in the absence of both carbon and nitrogen sources (Hackette et al., 1970). On the other hand, a similar requirement for carbon source but not nitrogen was demonstrated in yeast (Roon et al., 1975).

\section{$p H$, temperature and energy dependence of methylamine transport}

The initial rate of methylamine uptake was maximal at $\mathrm{pH} 6.0$ with approximately $50 \%$ of the maximum activity at $\mathrm{pH} 4.5$ and $8 . \mathrm{KCl}$ at $10 \mathrm{~mm}$ and above caused about $40 \%$ inhibition of transport activity. Transport was optimal at $30^{\circ} \mathrm{C}$ and had a $Q_{10}$ value of 2 measured between 20 and $30{ }^{\circ} \mathrm{C}$. Methylamine uptake was inhibited by more than $75 \%$ when inhibitors of energy metabolism such as dinitrophenol, sodium azide, $\mathrm{KCN}$ or $\alpha$-iodoacetamide were added at $1 \mathrm{~mm}$.

The intracellular accumulation of $\left[{ }^{14} \mathrm{C}\right]$ methylamine against a concentration gradient was investigated by the procedures described in Methods. The mycelium was incubated in the presence of $30 \mu \mathrm{M}\left(3 \times 10^{-5}\right.$ c.p.m. $\left.\mu \mathrm{mol}^{-1}\right)$ or $3 \mu \mathrm{M}\left(3 \times 10^{-6}\right.$ c.p.m. $\left.\mu \mathrm{mol}^{-1}\right)$ methylamine for $50 \mathrm{~min}$. In both treatments more than $85 \%$ of the extracted label was identified as methylamine by thin-layer chromatography. At this time the intracellular concentration of methylamine calculated on the whole cell volume (Breiman \& Barash, 1976) was $11 \mathrm{~mm}$ and $1 \mathrm{~mm}$ for the first and second treatments, respectively. This amount of methylamine represents a concentration gradient of at least 380:1 between the mycelial cells and external environment. 


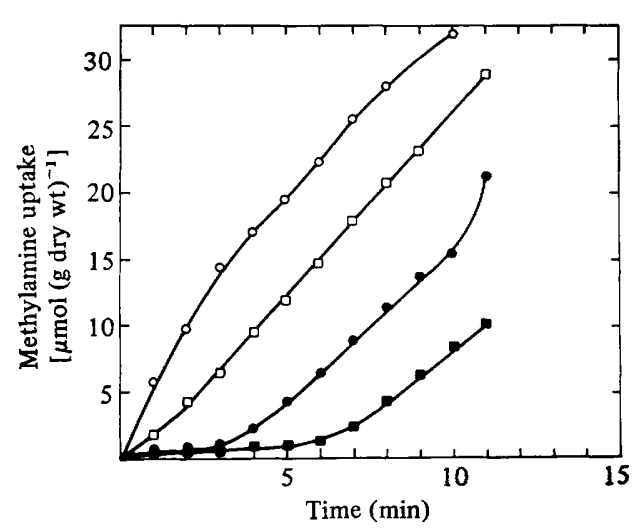

Fig. 3. Effect of $\mathrm{NH}_{4}{ }^{+}$concentration on the lag in methylamine uptake. Transport was assayed as described in Methods. Initial $\mathrm{NH}_{4}{ }^{+}$concentrations were $0.10 \mathrm{~mm}(\mathbf{D}), 0.05 \mathrm{~mm}\left(\mathrm{O}^{2}\right)$ and $0.03 \mathrm{~mm}$ $(\square)$; control (O).

\section{Specificity and kinetics of methylamine transport activity}

Ammonia was the strongest inhibitor of methylamine transport among a variety of amines and amides tested (Table 1). Significant inhibition was also observed with either glutamine or asparagine, whereas dimethylamine and ethylamine showed lower inhibition. Other amino acids tested only slightly decreased the initial rate of transport (results not shown). Similar inhibition by asparagine and glutamine were reported in other fungi (Hackette et al., 1970; Roon et al., 1975; Cook \& Anthony, 1978b).

The time course of methylamine transport in the presence of various concentrations of $\mathrm{NH}_{4}{ }^{+}$is shown in Fig. 3. The lag period before methylamine transport commenced was almost proportional to the initial $\mathrm{NH}_{4}{ }^{+}$concentration. Assuming that the lag period is a measure of the time required to transport $\mathrm{NH}_{4}{ }^{+}$into the mycelium, a rough estimation of the $\mathrm{NH}_{4}{ }^{+}$transport rates can be made as described by Hackette et al. (1970). An approximate rate of $6.5 \mu \mathrm{mol}(\mathrm{g} \text { dry wt) })^{-1} \mathrm{~min}^{-1}$ was calculated. This value is $66 \%$ of that reported for mycelial cells of $P$. chrysogenum (Hackette et al., 1970) and about $40 \%$ of that reported for germinated spores of $A$. nidulans (Cook \& Anthony, 1978a). The $K_{\mathrm{m}}$ and $V_{\max }$ values obtained for methylamine by extrapolation from a Lineweaver-Burk plot were $12 \cdot 5 \mu \mathrm{M}$ and $4 \cdot 1 \mu \mathrm{mol}$ (g dry wt) ${ }^{-1} \mathrm{~min}^{-1}$, respectively. $\mathrm{NH}_{4}{ }^{+}$competitively inhibited the entry of methylamine with a $K_{1}$ of approximately $8 \mu \mathrm{M}$.

\section{Dependence of methylamine transport on nitrogen source}

To determine the effect of the nitrogen source on the level of transport activity, the mycelium was grown on nitrate medium for $5 \mathrm{~d}$, harvested, washed and transferred into various media as described in Table 2 . Nitrogen starvation for $4 \mathrm{~h}$ decreased methylamine uptake by $60 \%$. These results indicate that the system for $\mathrm{NH}_{4}{ }^{+}$transport in $S$. botryosum differs in its regulation from those in $P$. chrysogenum and germinated conidia of $A$. nidulans which required nitrogen starvation for their development or derepression (Hackette et al., 1970; Cook \& Anthony, 1978 b). In yeast cells, the maximal rate of methylamine transport occurred when they were grown in the presence of $\mathrm{NH}_{4}{ }^{+}$(Roon et al., 1975), yet $\mathrm{NH}_{4}{ }^{+}$ almost completely abolished transport activity in $S$. botryosum (Table 2).

Cells incubated in the presence of nitrate showed the highest transport activity, whereas addition of glutamine, asparagine or $\mathrm{NH}_{4}{ }^{+}$to the nitrate medium decreased the transport rate about 40 -fold (Table 2). The most remarkable change in the intracellular pool following the addition of $\mathrm{L}$-amides or $\mathrm{NH}_{4}{ }^{+}$was the increase (4- to 15-fold) in the glutamine plus asparagine concentration (Table 3 ). In contrast to the amide pool, the intracellular $\mathrm{NH}_{4}{ }^{+}$ 
Table 2. Effect of preincubation with various nitrogen sources on methylamine transport

Mycelium was incubated in a shaker at $25^{\circ} \mathrm{C}$ in nitrate medium containing various nitrogen sources $(10 \mathrm{~mm})$ as indicated. After $4 \mathrm{~h}$ it was washed and used for transport assay under standard conditions.

$\begin{array}{lc}\text { Nitrogen source } & \begin{array}{c}\text { Transport rate } \\ {[\mu \mathrm{mol}} \\ \text { (g dry wt) }^{-1} \\ \left.\mathrm{~min}^{-1}\right]\end{array} \\ \mathrm{KNO}_{3} \text { (control) } & 4 \cdot 20 \\ \text { L-Glutamate } & 2 \cdot 47 \\ \text { L-Glutamine } & 0 \cdot 09 \\ \text { L-Asparagine } & 0 \cdot 10 \\ \mathrm{NH}_{4} \mathrm{Cl} & 0 \cdot 09 \\ \mathrm{Methylamine}^{*} & 1 \cdot 10 \\ \text { Without nitrate* } & 1 \cdot 68 \\ & \end{array}$

Table 3. Effect of different nitrogen sources on the pools of amides and $\mathrm{NH}_{4}{ }^{+}$

\begin{tabular}{|c|c|c|c|c|c|}
\hline \multirow[b]{3}{*}{ Amino acid or $\mathrm{NH}_{4}^{+}$} & \multicolumn{5}{|c|}{ Amino acid or $\mathrm{NH}_{4}^{+}$concn $\left[\mu \mathrm{mol}(\mathrm{g} \text { dry wt })^{-1}\right]$} \\
\hline & \multirow{2}{*}{$\begin{array}{l}\text { Nitrogen- } \\
\text { starved } \\
\text { mycelium* }\end{array}$} & \multicolumn{4}{|c|}{ Nitrogen source added (5 mM) } \\
\hline & & $\mathrm{KNO}_{3}$ & $\mathrm{NH}_{4} \mathrm{Cl}$ & Asparagine & Glutamine \\
\hline L-Glutamine $+\mathrm{L}$-asparagine & $3 \cdot 4$ & 6.9 & $40 \cdot 1$ & $101 \cdot 6$ & $27 \cdot 7$ \\
\hline Glutamate & $9 \cdot 17$ & $29 \cdot 5$ & $80 \cdot 1$ & $52 \cdot 0$ & $74 \cdot 7$ \\
\hline Total amino acids & $85 \cdot 7$ & $128 \cdot 0$ & $293 \cdot 0$ & $314 \cdot 0$ & $221 \cdot 0$ \\
\hline $\mathrm{NH}_{4}{ }^{+}$ & $9 \cdot 2$ & $13 \cdot 5$ & $20 \cdot 7$ & $17 \cdot 1$ & $22 \cdot 3$ \\
\hline
\end{tabular}

pool was significantly more stable, increasing only $1 \cdot 3$ - to $1 \cdot 7$-fold under the same conditions. Although the initial concentration of the nitrogen sources in the experiment described in Table 3 was lower $(5 \mathrm{~mm})$ than in Table $2(10 \mathrm{~mm})$ the level and proportion of the amides and amino acids in the intracellular pool were constant even at higher external concentrations of glutamine, asparagine or $\mathrm{NH}_{4}{ }^{+}$(Breiman, 1978). Consequently the two experiments can be compared and suggest that the $\mathrm{NH}_{4}+$ transport activity is inversely proportional to the intracellular concentration of asparagine and glutamine.

Our results support the hypothesis that L-amides (Hackette et al., 1970; Cook \& Anthony, $1978 b$ ) rather than $\mathrm{NH}_{4}{ }^{+}$(Pateman et al., 1974) may function as regulators of the $\mathrm{NH}_{4}{ }^{+}$ transport system in $S$. botryosum. It should be pointed out that due to compartmentation of amino acids and amides in fungi (Pateman \& Kinghorn, 1975), more direct evidence would be necessary for direct proof (Breiman \& Barash, 1978). L-Amides have been demonstrated as co-repressors of NADP-specific glutamate dehydrogenase, the major enzyme for $\mathrm{NH}_{4}{ }^{+}$ assimilation in $S$. botryosum (Breiman \& Barash, 1978). It is therefore reasonable to postulate that the accumulation of L-amides, which reflects the overall nitrogen sufficiency of the cells, suppresses the uptake and assimilation of $\mathrm{NH}_{4}{ }^{+}$. However, the requirement of nitrate for optimal development and activity implies that the present system does not function in the scavenging of low concentrations of $\mathrm{NH}_{4}{ }^{+}$during nitrogen starvation, as proposed for A. nidulans (Cook \& Anthony, 1978a). 


\section{REFERENCES}

BREIMAN, A. (1978). Studies on the uptake and assimilation of ammonium by Stemphylium botryosum. Ph.D. thesis, Tel-Aviv University.

Breiman, A. \& Barash, I. (1976). Characterization of L-asparagine transport systems in Stemphylium botryosum. Journal of Bacteriology 127, 1127-1135.

BreIMAN, A. \& BARASH, I. (1978). In vivo regulation of NADP-specific glutamate dehydrogenase by L-amides in Stemphylium botryosum. Journal of General Microbiology 106, 342-352.

ButTERY, P. Y. \& Rousell, E. V. (1971). Enzymatic assays for ammonia and L-glutamate in tissue extracts. Analytical Biochemistry 39, 297-310.

Cochrane, V. W. (1958). Physiology of Fungi. New York: John Wiley.

Cook, R. J. \& ANTHONY, C. (1978a). The ammonia and methylamine active transport system of Aspergillus nidulans. Journal of General Microbiology 109, 265-274.

Cook, R. J. \& Anthony, C. (1978b). Regulation by glutamine of ammonia transport in Aspergillus nidulans. Journal of General Microbiology 109, 275-286.

Gilpatrick, J. D. (1969). Role of ammonia in the control of avocado root rot with alfalfa meal soil amendment. Phytopathology 59, 973-978.
Hackette, S. L., Skye, G. E., Burton C. \& Segal, I. H. (1970). Characterization of an ammonium transport system in filamentous fungi with methylammonium $-{ }^{14} \mathrm{C}$ as the substrate. Journal of Biological Chemistry 245, 4241-4250.

Pateman, J. A., Dunn, E., Kinghorn, J. R. \& FORBES, E. C. (1974). The transport of ammonium and methylammonium in wild type and mutant cells of Aspergillus nidulans. Molecular and General Genetics 133, 225-236.

Pateman, J. A. \& Kinghorn, J. R. (1975). Nitrogen metabolism. In The Filamentous Fungi, vol. 2, pp. 159-237. Edited by J. E. Smith \& D. Berry. London: Edward Arnold.

Roon, R. J., Even, H. L., Dunlop, P. \& Larimore, F. L. (1975). Methylamine and ammonia transport in Saccharomyces cerevisiae. Journal of Bacteriology 122, 502-509.

Roon, R. J., LeVy, J. S. \& LARimore, F. (1977). Negative interactions between amino acid and methylamine/ammonia transport systems in Saccharomyces cerevisiae. Journal of Biological Chemistry 252, 3599-3604.

WARREN, K. S. (1962). Ammonia toxicity and pH. Nature, London 195, 47-49. 